ORIGINAL ARTICLE

\title{
Lung function decline in laboratory animal workers: the role of sensitisation and exposure
}

\author{
L Portengen, A Hollander, G Doekes, G de Meer, D Heederik
}

Occup Environ Med 2003;60:870-875

See end of article for authors' affiliations

.....................

Correspondence to: Dr L Portengen, Institute for Risk Assessment Sciences (IRAS), Utrecht University, PO Box 80176, 3508 TD, Utrecht, Netherlands: L.Portengen@iras.uu.nl

Accepted

20 November 2002

\begin{abstract}
Background: Little is known about the relation between allergic sensitisation and subsequent long term lung function changes in working populations exposed to sensitising agents.

Aims: To investigate whether exposure and work related sensitisation to laboratory animals are associated with lung function decline.

Methods: The relation between exposure and sensitisation to laboratory animal allergens and changes in lung function was investigated in a longitudinal study (median follow up 2.0 years) among 319 laboratory animal workers. Subjects who had been working with laboratory animals for less than 4 years $(n=102)$ were analysed separately, since an earlier cross sectional analysis had suggested a strong healthy worker effect in more experienced workers.

Results: In multiple regression analyses both sensitisation and exposure appeared to contribute independently to lung function decline in subjects who had been working with laboratory animals for less than 4 years, adjusting for gender, age, smoking, and atopy. Lung function decline was most pronounced in sensitised subjects who continued to be in contact with the animals to which they were sensitised, with estimated average excess declines in FEV,$F V C$, and MMEF of $83 \mathrm{ml} / \mathrm{y}(\mathrm{p}<0.05)$, $148 \mathrm{ml} / \mathrm{y}(\mathrm{p}<0.01)$, and $7 \mathrm{ml} / \mathrm{s} / \mathrm{y}(\mathrm{p}=0.9)$.

Conclusions: We conclude that exposure to laboratory animals is a significant risk factor for accelerated lung function decline, and that sensitised workers are especially at risk.
\end{abstract}

C linical studies in sensitised subjects suggest that continued exposure to sensitising agents can lead to chronic loss in lung function in subjects with occupational asthma, ${ }^{1-3}$ although this has primarily been evaluated in those exposed to low molecular weight allergens such as toluene diisocyanate ${ }^{45}$ and Western Red Cedar. ${ }^{67}$

However, virtually no data are available on long term changes in lung function from follow up studies in normal working populations and from workers exposed to high molecular weight sensitisers. Flood and coworkers ${ }^{8}$ reported similar declines in $\mathrm{FEV}_{1}$ over 11 years for 198 enzyme sensitised (that is, skin prick test positive) and 1484 nonsensitised enzyme detergent workers. Sensitised workers with respiratory hypersensitivity symptoms had been removed from further exposure. Several studies in laboratory animal workers suggest that exposure and/or sensitisation to laboratory animal allergens is associated with an accelerated decline in lung function. ${ }^{9-11}$ However, most of these studies lacked power and were therefore unable to explore effects of exposure and sensitisation separately.

The relation between common atopy, either defined as a positive skin prick test, the presence of serum IgE against common allergens, or increased levels of total IgE, and changes in lung function has been evaluated in several large population $^{12-18}$ and occupational ${ }^{19-21}$ studies, but with conflicting results.

Weiss and colleagues ${ }^{22}$ investigated the relation between exposure to allergens and longitudinal lung function decline in a selected group of subjects from the Normative Aging Study. Levels of cockroach allergens in house dust at follow up were significant predictors of annual decline in $\mathrm{FEV}_{1}$ in both asthmatic and non-asthmatic subjects. Relations between allergen levels and lung function decline were strongest in subjects with a positive skin test reaction compared to those without. No such associations were found for levels of mite or cat allergens.
Altogether these results suggest that lung function may decline more rapidly in subjects who are exposed to allergens, and in particular in those with work related allergic respiratory disease. We investigated whether exposure and work related sensitisation were associated with lung function decline in a follow up study among laboratory animal workers. In earlier reports regarding data from the first survey of this study, determinants of exposure and the relation between exposure and sensitisation to rat and mice have been described. ${ }^{23} 24$

\section{METHODS}

\section{Study design and subjects}

Data were used from a cross sectional survey conducted in 1992/93, and repeated in 1993/94 and 1994/95. Detailed description of the design and methods of data collection have been reported previously. ${ }^{23}$ Each survey included a questionnaire, skin prick testing, and lung function measurements. For this analysis only lung function data from the first and last survey were used, as change in lung function over a shorter period may be strongly influenced by short term variability, leading to loss of power. ${ }^{25}$

A complete dataset at the first survey was available for 507 subjects, of which 375 (74\%) also participated in the last survey. Lung function measurements were available for 319 $(85 \%)$.

Earlier analyses suggested the presence of a healthy worker effect, ${ }^{23}$ therefore data from workers who had been working with laboratory animals for more ( $\mathrm{n}=217$; "experienced" workers) or less than 4 years ( $\mathrm{n}=102$; "novice" workers) were analysed separately. This cut off point was chosen

Abbreviations: FEV, forced expiratory volume; FVC, forced vital capacity; MMEF, maximum mid-expiratory flow 
Main messages

- Exposure to laboratory animals in sensitised laboratory animal workers was a risk factor for longitudinal lung function decline in this cohort study.

- Estimated excess decline in FEV 1 and FVC for sensitised workers who continued to work with the animals to which they were sensitised was $83 \mathrm{ml} / \mathrm{y}$ and $148 \mathrm{ml} / \mathrm{y}$, respectively.

- No association was found between presence of symptoms of respiratory allergy and lung function change.

because most less experienced laboratory animal workers were PhD students and usually had a contract period of 4 years.

\section{Questionnaire}

The self administered questionnaire contained questions on smoking history, allergic symptoms due to common and occupational allergens, airway hyperreactivity, contact with laboratory animals, and occupational history. ${ }^{26}$ For most analyses in this paper only questionnaire data obtained at the first survey were used. Recent exposure to laboratory animals was defined as self reported contact with laboratory animals, faeces, or urine within the past 12 months. Allergic respiratory symptoms to laboratory animals were defined as the presence of self reported chest tightness, sneezing, or a runny nose during or after contact with laboratory animals.

\section{Skin prick testing}

Skin prick testing was performed as described previously ${ }^{26}$ with five common allergens (mixture of Dermatophagoides pteronyssinus and $D$ farinae; mixture of grass pollen; mixture of tree pollen; cat fur; dog fur; all from ALK Benelux, Houten, Netherlands), six occupational allergens (rat urine; rat fur; mouse urine; mouse fur; rabbit fur; guinea pig fur; all from ALK Benelux) and positive (histamine) and negative (PBS) controls. Common atopy was defined as a positive skin prick test (wheal size $\geqslant 3 \mathrm{~mm}$ ) against at least one common allergen. Laboratory animal sensitisation was defined as a positive skin prick test against at least one occupational allergen.

\section{Spirometry}

FVC, FEV 1 , and MMEF were recorded with a Vicatest V dry rolling seal spirometer (Jaeger, Breda, Netherlands). Measurements were performed according to the lung function protocol of the European Community for Steel and Coal. ${ }^{27}$ Lung function change was defined as the difference between lung function at the last and first survey divided by the time interval between surveys.

\section{Statistical analysis}

All statistical analyses were performed using SAS software (version 6.12; SAS Institute, Cary, NC). All continuous variables except the number of pack-years followed a normal distribution. Crude differences in prevalence rates or means between groups were compared using Fisher's exact test and Student's $t$ test. Differences in number of pack years were tested with a non-parametric rank sum test (Wilcoxon). Odds ratios were calculated by logistic regression (PROC GENMOD). The association between lung function change and laboratory animal sensitisation, exposure, and allergic symptoms was analysed by classical multiple regression analysis (PROC GENMOD). Independent variables which

\section{Policy implications}

- Since sensitisation is a risk factor for subsequent lung function decline, sensitised workers should be monitored more closely to limit the health impact and improve prognosis. Removal from exposure should also be considered for sensitised asymptomatic workers.

were associated $(p<0.2)$ both with lung function decline and with exposure, sensitisation, or the presence of symptoms to laboratory animals in univariate analysis, were considered possible confounders and included in the regression models, together with known predictors of respiratory function change (gender, age, smoking).

All statistical tests were performed two sided and a $\mathrm{p}$ value $<0.05$ was considered significant.

\section{RESULTS}

\section{Subject characteristics}

Median time interval between the first and last survey was 2.0 years (range 1.2-2.5). Table 1 presents personal characteristics of all subjects included in the study, as well as those who were lost to follow up. There was no significant difference in the prevalence of sensitisation or in gender, age, and height corrected lung function at the first survey, but subjects lost to follow up more often reported chronic and work related respiratory symptoms. More female than male subjects had been working with laboratory animals for less than 4 years, and subjects in this group were on average younger, smoked less, and were less frequently exposed to laboratory animals than those who had worked with laboratory animals for a longer period.

\section{Laboratory animal sensitisation, recent exposure, and allergic symptoms}

A positive skin prick test reaction to at least one of the four laboratory animal species was found in 88/319 follow up subjects $(28 \%)$. As in earlier analyses ${ }^{23} 24$ sensitisation to laboratory animals was strongly associated with common atopy (unadjusted OR 14, 95\% CI 7 to 28 ), asthma symptoms (unadjusted OR 3, 95\% CI 2 to 6), a history of nonoccupational allergy (unadjusted OR 3, 95\% CI 2 to 5), and symptoms of respiratory allergy to laboratory animals (unadjusted OR 5, 95\% CI 2 to 10). Compared to male laboratory workers, female workers were sensitised less often $(23 \% \vee 30 \%)$, although this was not statistically significant. Self reported exposure was positively associated with sensitisation in subjects working with laboratory animals for less than four years for rat allergens only (unadjusted OR $1.4,95 \%$ CI 0.4 to 5.7 ). No relation between sensitisation and smoking or other subject characteristics at the first survey was found.

\section{Lung function}

$\mathrm{FEV}_{1}$ and FVC at the first survey were somewhat higher than gender, age, and height corrected reference values, ${ }^{27}$ while MMEF was somewhat lower. No relation between lung function and laboratory animal sensitisation or recent exposure to laboratory animals was found, but subjects who reported allergic respiratory symptoms during or shortly after working with laboratory animals tended to have a lower $\mathrm{FEV}_{1}$ when compared to those without symptoms (mean (SD) $104 \%(19 \%)$ v $108 \%(12 \%)$; $\mathrm{p}=0.07)$.

Average annual declines in $\mathrm{FEV}_{1}, \mathrm{FVC}$, and MMEF (SD) in the entire cohort $(\mathrm{n}=319)$ were -41 (99) $\mathrm{ml} / \mathrm{y}, \quad-15$ (117) $\mathrm{ml} / \mathrm{y}$, and $-115(224) \mathrm{ml} / \mathrm{s} / \mathrm{y}$ respectively. In univariate 


\begin{tabular}{|c|c|c|c|c|}
\hline \multirow[b]{2}{*}{ Parameter } & \multirow[b]{2}{*}{$\begin{array}{l}\text { Lost to follow } \\
\text { up }(n=132) \ddagger\end{array}$} & \multirow[b]{2}{*}{$\begin{array}{l}\text { Available for } \\
\text { follow up } \\
(n=375) \ddagger\end{array}$} & \multicolumn{2}{|c|}{ Actual follow up $(n=319) \dagger$} \\
\hline & & & $\begin{array}{l}\text { Working with } \\
\text { animals }>4 \text { y } \\
(n=217) \ddagger\end{array}$ & $\begin{array}{l}\text { Working with } \\
\text { animals }<4 \text { y } \\
(n=102) \ddagger\end{array}$ \\
\hline Gender (female) & $51(39 \%)$ & $143(38 \%)$ & $60(28 \%)$ & $56(55 \%)^{* *}$ \\
\hline Age (y) & $33.6(9.0)$ & $35.4(9.8)$ & $39.3(8.7)$ & $28.6(7.0)^{\star *}$ \\
\hline Standing height $(\mathrm{cm})$ & $176.8(8.7)$ & $175.9(9.1)$ & $176.2(8.8)$ & $175.9(10.0)$ \\
\hline Body weight (kg) & $73.9(12.0)$ & 73.7 (11.9) & $74.6(11.6)$ & $71.8(12.0)$ \\
\hline Current smoker & $44(33 \%)$ & $86(23 \%)^{*}$ & $51(24 \%)$ & $20(20 \%)$ \\
\hline Former smoker & $24(18 \%)$ & $106(28 \%)^{*}$ & $78(36 \%)$ & $15(15 \%)^{* *}$ \\
\hline Pack-years (y) & $4.1(9.8)$ & $3.9(7.7)$ & $5.1(8.7)$ & $1.4(4.0)^{\star *}$ \\
\hline Common atopy & $61(46 \%)$ & $164(44 \%)$ & $99(46 \%)$ & $45(44 \%)$ \\
\hline Chronic respiratory symptoms & $48(36 \%)$ & $97(26 \%)^{*}$ & $56(26 \%)$ & $25(25 \%)$ \\
\hline Bronchitis symptoms & $19(14 \%)$ & $26(7 \%)^{* \star}$ & $18(8 \%)$ & $4(4 \%)$ \\
\hline Asthma symptoms & $36(27 \%)$ & $84(22 \%)$ & $47(22 \%)$ & $23(23 \%)$ \\
\hline History of non-occupational allergy & $38(29 \%)$ & $96(26 \%)$ & $60(28 \%)$ & $23(23 \%)$ \\
\hline Airway hyperreactivity & $22(17 \%)$ & $54(14 \%)$ & $28(13 \%)$ & $17(17 \%)$ \\
\hline Years worked with laboratory animals (y) & $8.7(7.9)$ & $10.8(10.1)^{\star}$ & $15.9(9.1)$ & $1.7(1.1)^{* *}$ \\
\hline Recently exposed to laboratory animals & $124(94 \%)$ & $335(89 \%)$ & $203(94 \%)$ & $82(80 \%)^{* *}$ \\
\hline Sensitised to laboratory animals & $42(32 \%)$ & $102(27 \%)$ & $62(29 \%)$ & $26(25 \%)$ \\
\hline $\begin{array}{l}\text { Symptoms of respiratory allergy to } \\
\text { laboratory animals }\end{array}$ & 37 (28\%) & $56(15 \%)^{* *}$ & $33(15 \%)$ & $15(15 \%)$ \\
\hline $\mathrm{FEV}_{1}(\%) \S$ & $106.9(11.6)$ & $106.8(13.4)$ & 108.0 (14.3) & $105.9(11.6)$ \\
\hline FVC (\%)§ & 110.8 (11.8) & 111.0 (13.2) & 112.8 (14.1) & $109.3(11.7)^{*}$ \\
\hline MMEF (\%)§ & $92.8(24.1)$ & $91.0(25.0)$ & $90.2(25.9)$ & $93.3(23.6)$ \\
\hline \multicolumn{5}{|c|}{$\begin{array}{l}{ }^{*} p<0.05 \text { for comparisons between subjects lost to follow up and subjects available for follow up or subjects in } \\
\text { follow up population working with laboratory animals for }>4 \text { years and those working for }<4 \text { years, respectively. } \\
{ }^{* *} p<0.01 \text { for comparisons between subjects lost to follow up and subjects available for follow up or subjects in } \\
\text { follow up population working with laboratory animals for }>4 \text { years and those working for }<4 \text { years, respectively. } \\
\text { tFiffy six subjects who were available for follow up did not participate in lung function testing. } \\
\text { tn (\%)/mean (SD). } \\
\text { \$Percentage of predicted value (sex, age, and height corrected). }{ }^{27}\end{array}$} \\
\hline
\end{tabular}

regression analysis lung function decline was significantly associated with gender, age, standing height, body weight, number of pack-years smoked, atopy, history of contact with laboratory animals, sensitisation against laboratory animal allergens, and symptoms of respiratory allergy to laboratory animals at the first survey (tables 2 and 3). Associations between work related sensitisation or exposure at the first survey and lung function decline were strongest in subjects who had been working with laboratory animals for less than four years. Both sensitisation and exposure to laboratory animals appeared to contribute independently to lung function decline in multiple regression models, adjusting for possible confounders gender, age, smoking, and common atopy (data not shown). As neither body weight nor standing height was associated with exposure, sensitisation, or symptoms to laboratory animals, they were not included in these models. To account for a potential modifying effect of sensitisation on the association between exposure and lung function change, a variable indicating whether subjects were sensitised to the animal species they reported working with was added to the model (tables 4 and 5). Lung function had declined most strongly in subjects who were exposed to the animals they were sensitised to. By adding coefficients for sensitisation and for sensitisation in combination with exposure, it can be calculated from these tables that estimated excess lung function decline in sensitised "novice"

Table 2 Univariate regression analysis of annual lung function change over two years in laboratory animal workers on subject characteristics in subjects working with laboratory animals for less than four years $(n=102)$

\begin{tabular}{|c|c|c|c|c|}
\hline Parameter & $\mathbf{n}$ & $\begin{array}{l}\Delta F E V 1(\mathrm{~m} / \mathrm{y}) \\
\beta(\mathrm{SE})\end{array}$ & $\begin{array}{l}\Delta F V C(\mathrm{ml} / \mathrm{y}) \\
\beta(\mathrm{SE})\end{array}$ & $\begin{array}{l}\triangle \text { MMEF }(\mathrm{ml} / \mathrm{s} / \mathrm{y}) \\
\beta \text { (SE) }\end{array}$ \\
\hline $\begin{array}{l}\text { Gender (female) } \\
\text { Age (/10 y) } \\
\text { Standing height }(/ 10 \mathrm{~cm}) \\
\text { Body weight }(/ 10 \mathrm{~kg}) \\
\text { Current smoker } \\
\text { Former smoker } \\
\text { Pack-years }(/ \mathrm{y}) \\
\text { Common atopy } \\
\text { Chronic respiratory symptoms } \\
\text { Bronchitis symptoms } \\
\text { Asthma symptoms } \\
\text { History of non-occupational allergy } \\
\text { Airway hyperreactivity } \\
\text { Years worked with laboratory animals (/y) } \\
\text { Recently exposed to laboratory animals } \\
\text { Sensitised to laboratory animals } \\
\text { Symptoms of respiratory allergy to laboratory } \\
\text { animals }\end{array}$ & $\begin{array}{r}20 \\
15 \\
45 \\
25 \\
4 \\
23 \\
23 \\
17 \\
\\
82 \\
26 \\
15\end{array}$ & $\begin{aligned} & 57.9(19.4)^{* *} \\
&- 12.5(14.4) \\
&- 20.9(9.9)^{*} \\
&- 12.1(8.3) \\
&- 3.4(25.3) \\
& 1.5(28.4) \\
& 1.0(2.5) \\
&- 36.2(19.9) \\
&- 41.4(23.0) \\
&- 80.7(51.2) \\
&- 31.2(23.9) \\
&- 43.2(23.7) \\
&- 31.1(26.8) \\
&- 12.0(9.2) \\
&- 48.6(24.9) \\
&- 48.4(22.6)^{*} \\
&-67.0(27.6)^{*}\end{aligned}$ & $\begin{aligned} & 41.1(22.8) \\
&-9.5(16.5) \\
&-18.3(11.4) \\
&-14.8(9.5) \\
&-13.1(28.9) \\
&-26.5(32.4) \\
& 2.3(2.9) \\
&-35.5(22.9) \\
&-4.6(26.7) \\
&-23.4(59.2) \\
& 2.6(27.5) \\
&-27.7(27.4) \\
&-26.1(30.8) \\
&-0.9(10.6) \\
& 4.9(29.0) \\
&-95.4(24.6)^{\star *} \\
&-86.9(31.3)^{\star *}\end{aligned}$ & $\begin{array}{c}85.6(38.7)^{*} \\
-21.2(28.3) \\
-25.2(19.6) \\
-30.1(16.2) \\
40.4(49.5) \\
-5.6(55.6) \\
-0.6(4.9) \\
-81.7(38.9)^{*} \\
-73.3(45.2) \\
-101.2(101.0) \\
-66.5(46.7) \\
-72.5(46.6) \\
-28.9(52.8) \\
-38.1(17.8)^{*} \\
-76.4(49.1) \\
-56.1(44.9) \\
-24.2(55.6)\end{array}$ \\
\hline
\end{tabular}


Table 3 Univariate regression analysis of annual lung function change over two years in laboratory animal workers on subject characteristics in subjects working with laboratory animals for more than four years $(n=217)$

\begin{tabular}{|c|c|c|c|c|}
\hline Parameter & $\mathbf{n}$ & $\begin{array}{l}\Delta \text { FEV } 1(\mathrm{ml} / \mathrm{y}) \\
\beta \text { (SE) }\end{array}$ & $\begin{array}{l}\Delta F V C(\mathrm{ml} / \mathrm{y}) \\
\beta \text { (SE) }\end{array}$ & $\begin{array}{l}\triangle M M E F(\mathrm{ml} / \mathrm{s} / \mathrm{y}) \\
\beta \text { (SE) }\end{array}$ \\
\hline Gender (female) & 60 & $36.5(14.3)^{*}$ & $39.6(17.4)^{*}$ & $10.1(35.5)$ \\
\hline Age $(/ 10 y)$ & & $-14.2(7.4)$ & $-25.7(8.9)^{\star *}$ & $-4.1(18.2)$ \\
\hline Standing height $(/ 10 \mathrm{~cm})$ & & $-10.7(7.4)$ & $-9.9(9.0)$ & $-9.6(18.1)$ \\
\hline Body weight $(/ 10 \mathrm{~kg})$ & & $-14.8(5.5)^{\star *}$ & $-20.8(6.6)^{* *}$ & $-7.8(13.7)$ \\
\hline Current smoker & 51 & $-6.5(15.3)$ & $-5.0(18.6)$ & $-34.8(37.4)$ \\
\hline Former smoker & 78 & $-4.2(13.6)$ & $-11.9(16.4)$ & $6.4(33.1)$ \\
\hline Pack-years (/y) & & $-2.2(0.7)^{\star *}$ & $-2.1(0.9)^{*}$ & $-2.5(1.8)$ \\
\hline Common atopy & 99 & $0.5(13.1)$ & $1.5(15.8)$ & $-11.2(31.9)$ \\
\hline Chronic respiratory symptoms & 56 & $7.3(14.9)$ & $7.8(18.0)$ & $32.5(36.2)$ \\
\hline Bronchitis symptoms & 18 & $-2.7(23.6)$ & $31.5(28.5)$ & $-62.9(57.4)$ \\
\hline Asthma symptoms & 47 & $3.4(15.8)$ & $11.7(19.1)$ & $16.4(38.6)$ \\
\hline History of non-occupational allergy & 60 & $15.6(14.5)$ & $31.5(17.5)$ & $5.5(35.5)$ \\
\hline Airway hyperreactivity & 28 & $5.3(19.5)$ & $12.2(23.6)$ & $20.3(47.4)$ \\
\hline Years worked with laboratory animals (/y) & & $-1.3(0.7)$ & $-1.8(0.9)^{*}$ & $-1.5(1.7)$ \\
\hline Recently exposed to laboratory animals & 203 & $-34.0(26.4)$ & $-24.4(32.0)$ & $-26.5(64.6)$ \\
\hline Sensitised to laboratory animals & 62 & $-11.2(14.4)$ & $-6.1(17.4)$ & $-42.7(35.1)$ \\
\hline $\begin{array}{l}\text { Symptoms of respiratory allergy to laboratory } \\
\text { animals }\end{array}$ & 33 & $32.6(18.0)$ & $61.1(21.6)^{* *}$ & $0.5(44.2)$ \\
\hline
\end{tabular}

laboratory animal workers who were exposed to the animal species to which they were sensitised was $-80 \mathrm{ml} / \mathrm{y}\left(\Delta \mathrm{FEV}_{1}\right)$, $-148 \mathrm{ml} / \mathrm{y}(\triangle \mathrm{FVC})$, and $-6 \mathrm{ml} / \mathrm{s} / \mathrm{y}(\triangle \mathrm{MMEF})$, compared to exposed but non-sensitised subjects. A similar analysis involving symptoms of laboratory animal allergy was not possible since only one "novice" worker reported symptoms to animals he was not exposed to.

As these associations were based on exposure data collected at the start of the follow up period, it was considered whether changes in exposure status during the follow up might have affected these relations. Unfortunately, subgroups that were exposed intermittently were too small to allow meaningful analysis. However, estimated excess lung function decline in 11 "novice" sensitised workers who continually reported exposure to the laboratory animals they were sensitised to $(\beta \quad(S D))$ was $-82.6 \quad(36.0) \mathrm{ml} / \mathrm{y}$ $\left.\begin{array}{llll}(\mathrm{p}<0.05), & -147.7 & (37.9) \mathrm{ml} / \mathrm{y} & (\mathrm{p}<0.01)\end{array}\right)$ and -6.8 (73.0) $\mathrm{ml} / \mathrm{s} / \mathrm{y}(\mathrm{p}=0.9)$ for $\Delta \mathrm{FEV}_{1}, \Delta \mathrm{FVC}$, and $\triangle \mathrm{MMEF}$ respectively, when compared to continually exposed but non-sensitised subjects. Exclusion of never exposed subjects had only minor effects on these estimates, which were very similar to those from the analysis using only exposure data from the first survey.

\section{DISCUSSION}

The results of this study suggest that exposure to laboratory animals allergens is a significant risk factor for developing accelerated airflow obstruction, especially in sensitised workers. Estimated average excess declines in $\mathrm{FEV}_{1}, \mathrm{FVC}$, and MMEF were $83 \mathrm{ml} / \mathrm{y}, 148 \mathrm{ml} / \mathrm{y}$, and $7 \mathrm{ml} / \mathrm{s} / \mathrm{y}$ in "novice" laboratory animal workers who were sensitised and were continually exposed to the animal species to which they were sensitised when compared to continually exposed, but nonsensitised subjects. Buist and Vollmer ${ }^{28}$ concluded that in order to develop clinically notable airflow obstruction, the average rate of decline in $\mathrm{FEV}_{1}$ over an adult life would need to be $>90 \mathrm{ml} / \mathrm{y}$ or about three times that in non-smokers. This would mean that exposed and sensitised laboratory animal workers in our study are at increased risk for developing clinically relevant airway obstruction. Although there was a clear trend towards increased lung function decline in exposed and sensitised laboratory animal workers, reference groups in some of these analyses were quite small, and the numerical value of the estimates should therefore be interpreted with caution.

Lung function had also declined faster in sensitised "experienced" laboratory animal workers, but associations with exposure were much weaker and not statistically significant.

Surprisingly, a positive association was found between the presence of symptoms of respiratory allergy and lung function change in workers with more than four years experience. However, from these symptomatic workers, 15 (45\%) no longer reported work related symptoms at the last

Table 4 Multiple regression of annual lung function change over two years on laboratory animal sensitisation, recent exposure, and the presence of respiratory symptoms in subjects working with laboratory animals for less than four years $(\mathrm{n}=102)$

\begin{tabular}{|c|c|c|c|c|}
\hline Parameter & $\mathbf{n}$ & $\begin{array}{l}\Delta \mathrm{FEV}_{1}(\mathrm{ml} / \mathrm{y}) \\
\beta(\mathrm{SE})\end{array}$ & $\begin{array}{l}\Delta F V C(\mathrm{ml} / \mathrm{y}) \\
\beta(\mathrm{SE})\end{array}$ & $\begin{array}{l}\triangle M M E F(\mathrm{ml} / \mathrm{s} / \mathrm{y}) \\
\beta \text { (SE) }\end{array}$ \\
\hline $\begin{array}{l}\text { Gender (female) } \\
\text { Age (/10 y) } \\
\text { Pack-years }(/ y) \\
\text { Former smoker } \\
\text { Common atopy } \\
\text { Recently exposed to laboratory animals } \\
\text { Sensitised to laboratory animals } \\
\text { Sensitised and exposed to the same laboratory animal } \\
\text { Symptoms of respiratory allergy to laboratory animals }\end{array}$ & $\begin{array}{l}56 \\
15 \\
45 \\
82 \\
26 \\
13 \\
15\end{array}$ & $\begin{aligned} & 44.7(19.4)^{*} \\
&-16.4(15.3) \\
& 0.5(2.5) \\
& 30.8(28.4) \\
&-10.2(20.9) \\
&-41.1(25.0) \\
& 11.6(30.4) \\
&-91.1(39.7)^{*} \\
&-22.0(28.6)\end{aligned}$ & $\begin{aligned} & 14.5(22.1) \\
&-9.8(17.4) \\
& 1.9(2.8) \\
& 1.3(32.3) \\
& 10.6(23.9) \\
& 24.0(28.5) \\
&-28.6(34.6) \\
&-119.4(45.2)^{* *} \\
&-37.7(32.6)\end{aligned}$ & $\begin{aligned} 83.7 & (40.7)^{*} \\
-22.1 & (32.0) \\
0.0 & (5.2) \\
7.7 & (59.5) \\
-65.3 & (43.9) \\
-105.9 & (52.4)^{*} \\
-34.7 & (63.7) \\
28.4 & (83.2) \\
30.4 & (60.0)\end{aligned}$ \\
\hline
\end{tabular}




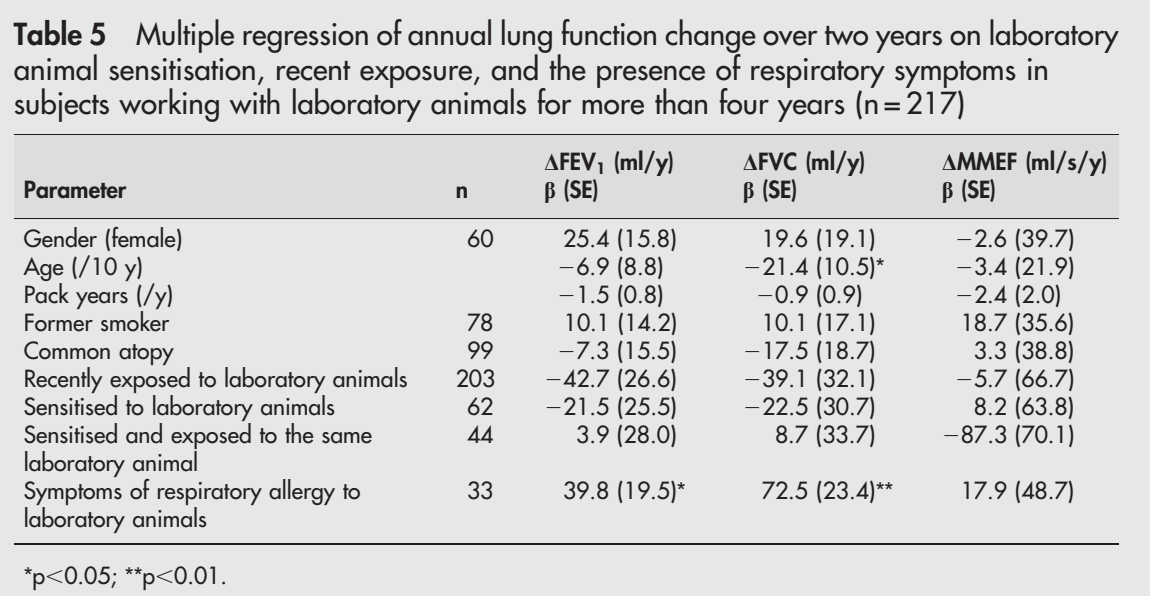

survey, despite the fact that most were still working with the animals for which they had reported symptoms.

Decline in FVC was paralleled by a similar decline in $\mathrm{FEV}_{1}$ in most subjects, suggesting that the reduction in FVC was the result of airways obstruction. It has been suggested that MMEF could be a sensitive index to detect mild airflow obstruction. ${ }^{27}$ However, changes in MMEF in our study did not correlate well with either changes in FVC or FEV 1 . This could be explained by the fact that MMEF is calculated over the middle half of the FVC, and changes in MMEF are therefore hard to interpret when the vital capacity also changes.

The absence of an association between exposure to laboratory animals and lung function decline in sensitised "experienced" laboratory animal workers may be explained by a healthy worker effect. Subjects who were lost to follow up reported allergic symptoms to common and work related allergens more frequently and were also more often sensitised to the animals they were working with. When comparing our results with those of other groups it should therefore be considered that we observed the most marked relations in "novice" laboratory animal workers.

Misclassification of sensitisation, exposure, symptoms, or lung function decline may have occurred in our study, but is likely to have been non-differential and will therefore probably have resulted in underestimation of the strength of the associations.

These results confirm and extend some of the findings in the few other longitudinal studies in laboratory animal workers. In a small Swedish study by Renström and colleagues, ${ }^{9}$ average changes in $\mathrm{FEV}_{1}$ and FVC after a median follow up of 18 months were $-150 \mathrm{ml}$ and $-10 \mathrm{ml}$ in nine exposed laboratory technician students with laboratory animal allergy (LAA; defined as the presence of IgE and/or symptoms) compared to $-50 \mathrm{ml}$ and $0 \mathrm{ml}$ in 29 students without LAA (mean age of subjects at follow up 25 years). In the paper by Sjösted and colleagues, ${ }^{10}$ decline in lung function was expressed as a percentage of baseline lung function. They reported a decline in $\mathrm{FEV}_{1}$ of $-7.5 \%$ over a period of fiveyears in 22 exposed workers with laboratory animal related symptoms and of $-2.2 \%$ in 27 subjects without chemical or laboratory animal related symptoms (mean age of subjects 42 years). Declines in FVC in both groups over the same period were $-2.2 \%$ and $-1.0 \%$ respectively.

Fuortes and colleagues ${ }^{11}$ reported a mean decline in $\mathrm{FEV}_{1}$ of $-328 \mathrm{ml}$ after 24 months of follow up in a group of 22 previously unexposed animal workers. This was significantly more than the $-132 \mathrm{ml}$ that was recorded in the control group of 16 non-exposed "wet" laboratory workers. However, loss to follow up in their study was considerable $(78 \%$ and $82 \%$ in animal exposed and unexposed groups respectively).

Only a modest and not statistically significant association was found between common atopy and lung function decline in this population of laboratory animal workers. Possible explanations include differences in potency, exposure level, and temporal exposure pattern between common and work related allergens. Alternatively, given the strong association between common atopy and laboratory animal sensitisation, it seems likely that those atopic workers that have not (yet) been sensitised to laboratory animal allergens are different from those that have been sensitised and may be less prone to experience allergic reactions or suffer lung function decline.

Based on their experience with subjects with occupational asthma, Malo and colleagues ${ }^{29}$ have proposed a model in which chronic inflammation develops after sensitisation, but possibly before the occurrence of symptoms. From clinical studies investigating inflammatory changes in the lungs of patients with asthma it has become clear that similar changes (but less pronounced) can be found in the lungs of atopic individuals without clinically diagnosed asthma. ${ }^{30-33}$ It is therefore possible that lung function decline in sensitised laboratory animal workers is the result of chronic low level inflammation caused by continued exposure to allergens. As post-bronchodilator spirometry was not assessed, it is unfortunately not possible to evaluate whether this apparent loss in lung function reflects development of occupational asthma or chronic airflow limitation.

Although small sample size and short follow up hamper interpretation of these results, exposure to laboratory animals seems to be a serious risk factor for the development of clinically relevant airway obstruction over a period of just a few years, especially in sensitised workers. This may occur in the absence of overt symptoms of respiratory allergy. Because of the implications for occupational hygiene and medicine practice, these results will need to be verified in larger and longer follow up studies.

\section{ACKNOWLEDGEMENTS}

Supported by grant no. 99.33 from the Dutch Asthma Foundation.

\section{Authors' affiliations}

L Portengen, A Hollander, G Doekes, G de Meer, D Heederik, Institute for Risk Assessment Sciences (IRAS), Utrecht University, Netherlands

\section{REFERENCES}

1 Hendrick DJ. Prognosis in occupational asthma. Thorax 1985;40:241-3.

2 Paggiaro PL, Vagaggini B, Bacci E, et al. Prognosis of occupational asthma. Eur Respir J 1994;7:761-7.

3 Venables KM, Chan-Yeung M. Occupational asthma. Lancet 1997:349:1465-9. 
4 Paggiaro PL, Loi AM, Rossi O, et al. Follow up study of patients with respiratory disease due to toluene diisocyanate (TDI). Clin Allergy 1984;14:463-9

5 Pisati G, Baruffini A, Zedda S. Tolvene diisocyanate induced asthma: outcome according to persistence or cessation of exposure. $\mathrm{Br} J$ Ind Med 1993;50:60-4

6 Cote J, Kennedy S, Chan-Yeung M. Outcome of patients with cedar asthma with continuous exposure. Am Rev Respir Dis 1990;141:373-6.

7 Lin FJ, Dimich-Ward H, Chan-Yeung M. Longitudinal decline in lung function in patients with occupational asthma due to western red cedar. Occup Environ Med 1996;53:753-6.

8 Flood DF, Blofeld RE, Bruce CF, et al. Lung function, atopy, specific hypersensitivity, and smoking of workers in the enzyme detergent industry over 11 years. Br J Ind Med 1985;42:43-50

9 Renström A, Malmberg P, Larsson K, et al. Allergic sensitization is associated with increased bronchial responsiveness: a prospective study of allergy to laboratory animal. Eur Respir J 1995:8:1514-19.

10 Sjöstedt L, Willers S, Ørbæk P. A follow-up study of laboratory animal exposed workers: the influence of atopy for the development of occupational asthma. Am J Ind Med 1993;24:459-69.

11 Fuortes L, Weih L, Pomrehn P, et al. Prospective epidemiologic evaluation of laboratory animal allergy among university employees. Am J Ind Med 1997; 32:665-9

12 Tracey M, Villar A, Dow $L$, et al. The influence of increased bronchial responsiveness, atopy, and serum IgE on decline in $\mathrm{FEV}_{1}$. A longitudinal study in the elderly. Am J Respir Crit Care Med 1995;151:656-62.

13 Vollmer WM, Buist AS, Johnson LR, et al. Relationship between serum IgE and cross-sectional and longitudinal FEV1 in two cohort studies. Chest 1986;90:416-23.

14 Parker DR, O'Connor GT, Sparrow D, et al. The relationship of nonspecific airway responsiveness and atopy to the rate of decline of lung function. The Normative Aging Study. Am Rev Respir Dis 1990; 141:589-94.

15 Shadick NA, Sparrow D, O'Connor GT, et al. Relationship of serum IgE concentration to level and rate of decline of pulmonary function: the Normative Aging Study. Thorax 1996;51:787-92.

16 Gottlieb DJ, Sparrow D, O'Connor GT, et al. Skin test reactivity to common aeroallergens and decline of lung function. The Normative Aging Study. Am J Respir Crit Care Med 1996;153:561-6.

17 Westeel V, Julien S, De Champs C, et al. Relationships of immunoglobulins E and $G$ sensitization to respiratory function in dairy farmers. Eur Respir J 2000;16:886-92

18 Taylor RG, Joyce H, Gross E, et al. Bronchial reactivity to inhaled histamine and annual rate of decline in FEVI in male smokers and ex-smokers. Thorax 1985;40:9-16.
19 Tabona M, Chan-Yeung M, Enarson D, et al. Host factors affecting longitudinal decline in lung spirometry among grain elevator workers. Chest 1984;85:782-6.

20 Annesi I, Neukirch F, Orvoen-Frija E, et al. The relevance of hyperresponsiveness but not of atopy to FEVI decline. preliminary results in a working population. Bull Eur Physiopathol Respir 1987;23:397-400.

21 Annesi I, Oryszczyn MP, Frette C, et al. Total circulating lgE and FEVI in adult men. An epidemiological longitudinal study. Chest 1992;101:642-8.

22 Weiss ST, O'Connor GT, DeMolles D, et al. Indoor allergens and longitudinal $\mathrm{FEV}_{1}$ decline in older adults: The Normative Aging Study. J Allergy Clin Immunol 1998;101:720-5.

23 Hollander A, Heederik D, Doekes G. Respiratory allergy to rats: exposureresponse relationships in laboratory animal workers. Am J Respir Crit Care Med 1997; 155:562-7.

24 Hollander A, Heederik D, Doekes G, et al. Determinants of airborne rat and mouse urinary allergen exposure. Scand J Work Environ Health 1998;24:228-35

25 Berry G. Longitudinal observations. Their usefulness and limitations with special reference to the forced expiratory volume. Bull Physiopathol Respir (Nancy) 1974;10:643-56.

26 Hollander A, Doekes G, Heederik D. Cat and dog allergy and total lgE as risk factors of laboratory animal allergy. J Allergy Clin Immunol 1996:98:545-54.

27 Quanier PH, Tammeling GJ, Cotes JE, et al. Lung volumes and forced ventilatory flows. Report of the Working Party on Standardization of Lung Function Tests, European Community for Steel and Coal. Official Statement of the European Respiratory Society. Eur Respir J Suppl 1993;16:5-40.

28 Buist AS, Vollmer WM. The use of lung function tests in identifying factors that affect lung growth and aging. Stat Med 1988;7:11-18.

29 Malo JL, Ghezzo H, D'Aquino C, et al. Natural history of occupational asthma: relevance of type of agent and other factors in the rate of development of symptoms in affected subjects. J Allergy Clin Immunol 1992:90:937-44.

30 Shaver JR, O'Connor JJ, Pollice $M$, et al. Pulmonary inflammation after segmental ragweed challenge in allergic asthmatic and nonasthmatic subjects. Am J Respir Crit Care Med 1995; 152:1 189-97.

31 Diukanovic R, Lai CK, Wilson JW, et al. Bronchial mucosal manifestations of atopy: a comparison of markers of inflammation between atopic asthmatics, atopic nonasthmatics and healthy controls. Eur Respir J 1992;5:538-44.

32 Howarth PH, Wilson J, Djukanovic R, et al. Airway inflammation and atopic asthma: a comparative bronchoscopic investigation. Int Arch Allergy Appl Immunol 1991;94:266-9.

33 Bradley BL, Azzawi M, Jacobson M, et al. Eosinophils, T-lymphocytes, mast cells, neutrophils, and macrophages in bronchial biopsy specimens from atopic subjects with asthma: comparison with biopsy specimens from atopic subjects without asthma and normal control subjects and relationship to bronchial hyperresponsiveness. J Allergy Clin Immunol 1991;88:661-74.

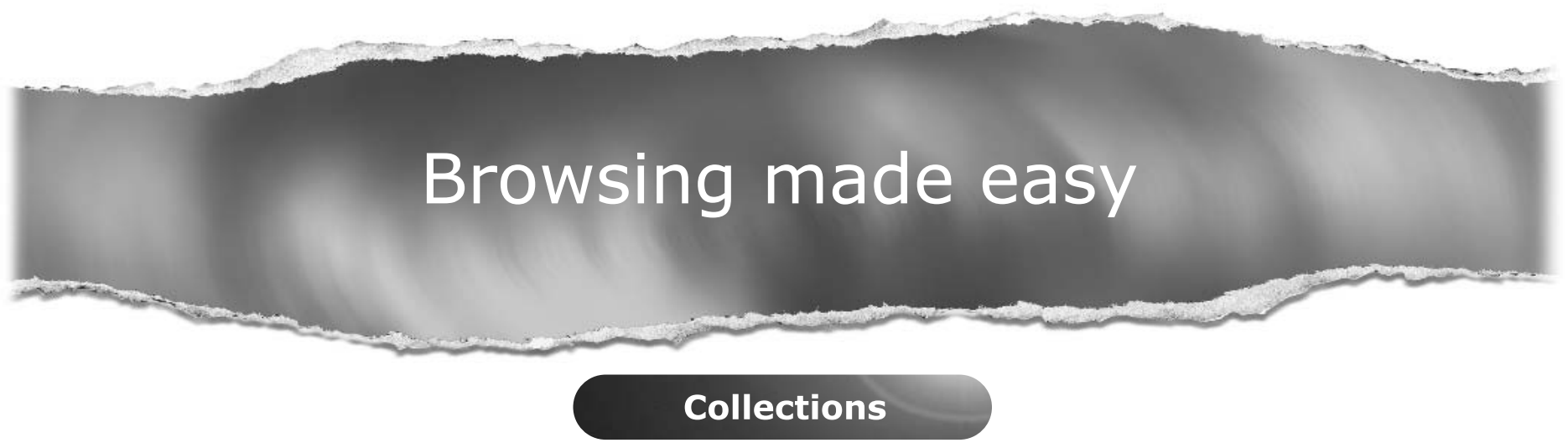

With a single click Collections allows you to find all articles that have been published in your chosen subject. Select from over 200 clinical and non-clinical topic collections and/or cross search other specialist journals, the BMJ and Cochrane Reviews

www.occenvmed.com 